\title{
Essential Mineral Elements Profile of 22 Accessions of Okra (Abelmoschus spp (L.)) From Eight Regions of Ghana
}

\author{
J. K. Ahiakpa ${ }^{1}$, E. K. Quartey ${ }^{2}$, G. Amenorpe ${ }^{2}$, G. Y. P. Klu ${ }^{1}$, W. S. K. Agbemavor ${ }^{3}$ \& H. M. Amoatey ${ }^{1,2}$ \\ ${ }^{1}$ Graduate School of Nuclear and Allied Sciences, Department of Nuclear Agriculture and Radiation Processing, \\ University of Ghana, Atomic-Accra, Ghana \\ ${ }^{2}$ Nuclear Agriculture Centre, Biotechnology and Nuclear Agriculture Research Institute, Ghana Atomic Energy \\ Commission, Accra, Ghana \\ ${ }^{3}$ Radiation Technology Centre, Biotechnology and Nuclear Agriculture Research Institute, Ghana Atomic \\ Energy Commission, Accra, Ghana \\ Correspondence: J. K. Ahiakpa, Graduate School of Nuclear and Allied Sciences, Department of Nuclear \\ Agriculture and Radiation Processing, University of Ghana, P. O. Box AE 1, Atomic-Accra, Ghana. Tel: \\ 233-0-264-663-941 / 233-0-277-786-645. E-mail: jnckay@gmail.com
}

\author{
Received: January 14, 2014 Accepted: February 18, 2014 Online Published: April 15, 2014 \\ doi:10.5539/jas.v6n5p18 URL: http://dx.doi.org/10.5539/jas.v6n5p18
}

\begin{abstract}
Five (5) essential macro, three (3) micro and two (2) trace mineral elements were determined in fresh fruits of twenty-two (22) accessions of okra using Instrumental Neutron Activation Analysis (INAA). These were correlated to assess the level of associations existing between these elements. Concentrations of these elements were juxtaposed with their recommended daily dietary intake (RDI) in the individual accessions of okra and their variability with other traits examined for future improvement works towards breeding for high or low micro nutrient containing variety (ies).
\end{abstract}

Keywords: Abelmoschus spp, accessions, INAA, mineral elements, health risk, RDI, nutrition

\section{Introduction}

Okra, (Abelmoschus spp (L.)), is prominently featured in nearly every market in Africa. In Ghana, it is the fourth most popularly patronised vegetable after tomatoes, pepper and garden eggs (Oppong-Sekyere et al., 2012; Sinnadurai, 1973). The world okra production, as of 2010, was estimated at 6.9 million tonnes with Asia leading the production by $75.92 \%$ followed by Africa $(23.41 \%)$ and the Americas $(0.54 \%)$ (FAOSTAT, 2012). On the whole, India is the leading producer of okra with over $70 \%$ of the total world production, followed by Nigeria, Pakistan, Sudan, Ghana, Egypt and Iraq (FAOSTAT, 2012; Gulsen et al., 2007). Okra is usually consumed fresh and in sauces and soups. It is used by the growing fast food, hotel and restaurant industry in Asia, the Americas, Africa and many other parts of the globe (Lamont Jr., 1999; Tyler et al., 1989), just like any other vegetable. Okra is consumed almost daily and traded by a broad range of market participants worldwide.

In Ghana, okra is traded in the fresh state in almost all markets during the rainy season and in a dehydrated form during the dry seasons. Essential mineral elements are elements that are indispensable to the human body and yet cannot be produced by the body. Approximately, the edible portion of the fruit contains $88.6 \mathrm{~g}$ of water, $36 \mathrm{kcal}$ energy, $2.10 \mathrm{~g}$ protein, $8.20 \mathrm{~g}$ carbohydrate, $0.20 \mathrm{~g}$ fat, $1.70 \mathrm{~g}$ fibre, together with small amounts of $\beta$-carotene $(185.00 \mu \mathrm{g})$, riboflavin $(0.08 \mathrm{mg})$, thiamine $(0.04 \mathrm{mg})$, niacin $(0.60 \mathrm{mg})$, ascorbic acid $(47.00 \mathrm{mg})$ (Kolawole et al., 2011; Saifullah \& Rabbani, 2009). Okra is also a good source of vitamin B, some essential minerals (Lamont Jr., 1999), rhamnose (22\%), galacturonic acid (27\%) and amino acids (11\%) (Benchasri, 2012).

\section{Materials and Methods}

\subsection{Experimental Site}

The experiment was conducted at the Ghana Research Reactor 1 (GHARR-1), the Nuclear Agriculture Research Centre (NARC) and the Radiation Technology Centre (RTC) of the Ghana Atomic Energy Commission, Kwabenya (Accra), Ghana. Instrumental Neutron Activation Analysis (INAA) was employed for the 
determination of variability in composition of mineral elements concentration in the fresh fruits of 22 accessions of okra assembled from eight geographical regions of Ghana.

\subsection{Okra Sample Preparation for Elemental Analysis}

Five (5) fruits of each of the 22 accessions were sliced into several pieces and put into plastic bowls and lyophilised (freeze-dried) for $48 \mathrm{hrs}$ in a CHRIST FREEZE DRYER before blending into fine powder. Samples were pulverised and put into clean plastic containers and shaken thoroughly to ensure uniformity before weighing. 200 $\mathrm{mg}$ of each sample (accession) was weighed into small polyethylene vials, labelled and hot sealed. The polyethylene capsules of diameter $1.2 \mathrm{~cm}$ and height $2.35 \mathrm{~cm}$ containing the samples were in turn, each put into a bigger polyethylene capsule of diameter $1.6 \mathrm{~cm}$ and height $5.5 \mathrm{~cm}$ (Rabbit capsule). Standard Reference material 1547 Peach Leaves from the National Institute of Technology and 1547 Citrus Leaves and blanks were equally prepared in the same manner as the test samples. Each sample was then irradiated by means of the Ghana Nuclear Research Reactor (GHARR-1) for 1 minute to detect short radionuclides. This was immediately followed by quantification of the samples.

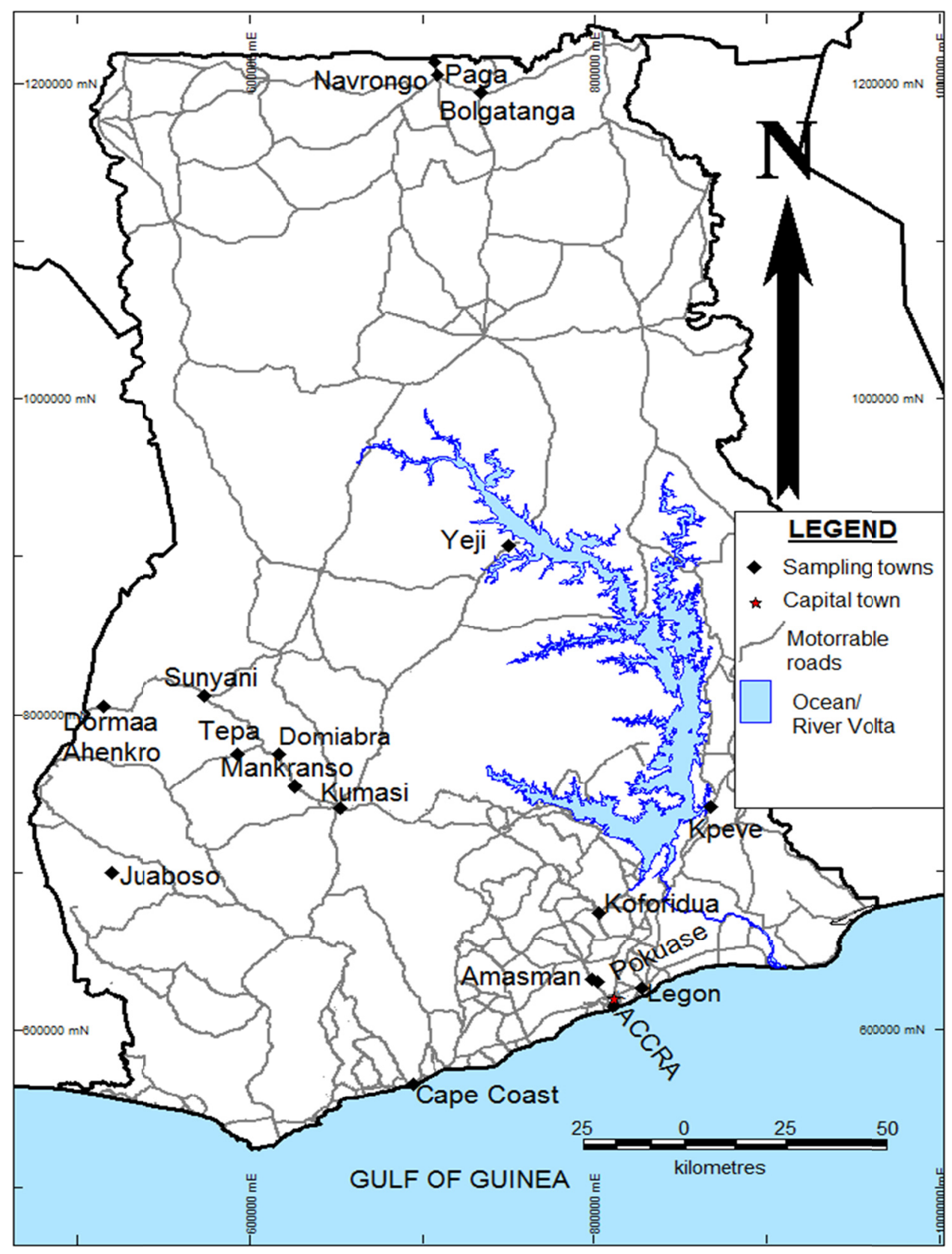

Figure 1. Map of Ghana showing locations where various accessions were collected 


\subsection{Sample Irradiation and Counting}

Lyophilised fresh fruits of okra and controls were irradiated in the Ghana Research Reactor (GHARR-1) at the Ghana Atomic Energy Commission, operating at $15 \mathrm{KW}$ at a thermal flux of $5 \times 10^{11} \mathrm{ncm}^{-2} \mathrm{~s}^{-1}$. Samples were transferred into irradiation sites via pneumatic transfer system at a pressure of $0.6 \mathrm{Mpa}$. The irradiation was categorised according to the half-life of the element of interest. For, ${ }^{27} \mathrm{Mg},{ }^{66} \mathrm{Cu}$, and ${ }^{38} \mathrm{Cl}$ samples were irradiated for two minutes and counted for ten minutes. For medium lived radionuclides like $\mathrm{K}, \mathrm{Na}$, samples were irradiated for one hour and delayed for $24 \mathrm{hrs}$ with ten minutes counting. After the irradiation, radioactivity measurements of induced radionuclide were performed by a PC-based $\gamma$-ray spectrometry set-up. This consisted of an n-type HPGe detector coupled to a computer based multi-channel analyser (MCA) via electronic modules. The relative efficiency of the detector is $25 \%$ with energy resolution of $1.8 \mathrm{keV}$ at a $\gamma$-ray energy of $1332 \mathrm{keV}$ of ${ }^{60} \mathrm{Co}$. Through appropriate choice of cooling-time, detector's dead time was controlled to be less than $10 \%$. Identification of $\gamma$-ray of product radionuclide was done through the energies and quantitative analysis of the concentration was achieved using the $\gamma$-ray spectrum analysis software, ORTEC MEASTRO-32.

\subsection{Data Analyses}

The Completely randomised design (CRD) was used with three replicates. They were evaluated for statistical significance with one-way analysis of variance (ANOVA) and means separated by the Duncan's multiple range test (Statgraphics (2010) Centurion XVI, version 16.1.11, USA) and expressed as the Mean upon three independent analyses. A p-value of 0.05 or less was considered as statistically significant.

\section{Results and Discussion}

\subsection{Concentrations of Ten Essential Elements in 22 Accessions of Abelmoshus spp L.}

Concentrations of five essential macro elements $(\mathrm{Ca}, \mathrm{Cl}, \mathrm{K}, \mathrm{Mg}$ and $\mathrm{Na}$ ), three micro elements ( $\mathrm{Al}, \mathrm{Cu}$ and $\mathrm{Mn}$ ) and two trace elements (As and $\mathrm{Br}$ ) detected by Instrumental Neutron Activation Analysis (INAA) in 22 accessions of okra are shown in Table 1. Yeji-Local registered the minimum $(10.12 \pm 1.52 \mathrm{mg} / \mathrm{kg})$ while Asontem-NV recorded the maximum $(95.18 \pm 13.79 \mathrm{mg} / \mathrm{kg}) \mathrm{Ca}$ content. Concentration of $\mathrm{Cl}$ recorded among the various okra accessions ranged from $10.85 \pm 1.63 \mathrm{mg} / \mathrm{kg}$ in Cape to $95.45 \pm 14.32 \mathrm{mg} / \mathrm{kg}$ in Mamolega. Similarly, the accession Indiana recorded the minimum concentration $(13.42 \pm 2.01 \mathrm{mg} / \mathrm{kg}$ ) of K with Nkran Nkuruma recording the maximum concentration $(97.43 \pm 14.61 \mathrm{mg} / \mathrm{kg})$. Asontem $\mathrm{NV}$ had the minimum concentration of $\mathrm{Mg}$ $(40.09 \pm 6.01 \mathrm{mg} / \mathrm{kg})$ while Asontem-BAR registered the maximum content $(61.52 \pm 9.23 \mathrm{mg} / \mathrm{kg})$. Asontem-ASR registered the minimum concentration $(16.32 \pm 2.45 \mathrm{mg} / \mathrm{kg})$ of $\mathrm{Na}$ while Mamolega recorded the maximum concentration $(778.5 \pm 11.60 \mathrm{mg} / \mathrm{kg})$.

Table 1. Concentration of ten mineral elements in 22 accessions of Okra $\left(\mathrm{mg} / \mathrm{kg}^{*}\right)$

\begin{tabular}{|c|c|c|c|c|c|c|c|c|c|c|}
\hline \multirow[b]{2}{*}{ Accession } & \multicolumn{4}{|c|}{ Macro elements } & \multicolumn{4}{|c|}{ Micro elements } & \multicolumn{2}{|c|}{ Trace elements } \\
\hline & $\mathrm{Ca}$ & $\mathrm{Cl}$ & $\mathbf{K}$ & Mg & $\mathrm{Na}$ & Al & $\mathrm{Cu}$ & Mn & As & $\mathrm{Br}$ \\
\hline Agric Type I & $82.25 \pm 12.34$ & $54.81 \pm 8.22$ & $27.21 \pm 4.08$ & $45.09 \pm 6.76$ & $189.0 \pm 28.24$ & $32.84 \pm 5.29$ & nd & $14.59 \pm 2.95$ & $1.27 \pm 0.19$ & $20.01 \pm 3.00$ \\
\hline Agric Short Fruit & $10.34 \pm 1.55$ & $69.17 \pm 10.37$ & $92.14 \pm 13.82$ & $48.57 \pm 7.29$ & $205.26 \pm 30.79$ & $42.72 \pm 6.88$ & nd & $15.53 \pm 2.92$ & $\mathrm{Nd}$ & $21.56 \pm 2.23$ \\
\hline Asante Type II & $90.92 \pm 13.64$ & $71.28 \pm 10.69$ & $19.07 \pm 2.86$ & $50.10 \pm 7.52$ & $279.3 \pm 40.99$ & $37.76 \pm 6.04$ & nd & $17.07 \pm 3.28$ & $1.57 \pm 0.24$ & $25.65 \pm 3.85$ \\
\hline Asontem NV & $99.18 \pm 13.79^{*}$ & $81.39 \pm 12.20$ & $16.04 \pm 2.41$ & $40.09 \pm 6.01$ & $190.1 \pm 28.52$ & $47.96 \pm 7.67$ & nd & $15.68 \pm 2.99$ & $1.88 \pm 0.28$ & $29.96 \pm 4.49$ \\
\hline Asontem-ASR & $89.26 \pm 13.39$ & $61.53 \pm 9.23$ & $23.80 \pm 3.57$ & $54.75 \pm 8.21$ & $16.32 \pm 2.45$ & $33.80 \pm 5.41$ & nd & $15.56 \pm 2.93$ & $10.30 \pm 1.55$ & $15.54 \pm 2.33$ \\
\hline Asontem-BAR & $11.13 \pm 1.67$ & $88.19 \pm 13.23$ & $19.81 \pm 2.97$ & $61.52 \pm 9.23^{*}$ & $191.5 \pm 28.25$ & $37.17 \pm 5.95$ & $186.5 \pm 27.98$ & $14.45 \pm 2.77$ & $1.99 \pm 0.30$ & $31.64 \pm 4.75$ \\
\hline Asontem-ER & $72.59 \pm 10.87$ & $62.11 \pm 9.32$ & $18.31 \pm 2.75$ & $42.95 \pm 6.44$ & $277.0 \pm 41.55$ & $42.50 \pm 6.80$ & nd & $13.31 \pm 2.64$ & $2.33 \pm 0.35$ & $38.42 \pm 5.76$ \\
\hline Asontem-GAR & $96.21 \pm 14.43$ & $93.78 \pm 14.07$ & $17.88 \pm 2.68$ & $47.59 \pm 7.14$ & $590.4 \pm 88.56$ & $35.96 \pm 5.75$ & nd & $20.35 \pm 3.81$ & $1.62 \pm 0.24$ & $25.72 \pm 3.86$ \\
\hline Atomic & $76.91 \pm 11.54$ & $36.84 \pm 5.53$ & $16.97 \pm 2.55$ & $48.53 \pm 7.28$ & $362.6 \pm 54.39$ & $37.34 \pm 5.94$ & $165.6 \pm 24.84$ & $16.47 \pm 3.12$ & $3.25 \pm 0.49$ & $51.86 \pm 7.78$ \\
\hline Cape & $11.71 \pm 1.76$ & $10.85 \pm 1.63$ & $19.48 \pm 2.92$ & $54.70 \pm 8.21$ & $385.6 \pm 57.16$ & $38.08 \pm 6.13$ & $424.5 \pm 63.67$ * & $25.21 \pm 4.84$ & $2.24 \pm 0.34$ & $36.20 \pm 5.43$ \\
\hline Clemson Spineless & $73.08 \pm 10.96$ & $51.37 \pm 7.71$ & $76.43 \pm 11.46$ & $43.96 \pm 6.59$ & $221.41 \pm 33.21$ & $51.39 \pm 8.17$ & nd & $17.07 \pm 3.12$ & $\mathrm{Nd}$ & $41.62 \pm 6.24$ \\
\hline Mean & $64.31 \pm 9.64$ & $64.73 \pm 9.71$ & $32.06 \pm 4.81$ & $49.99 \pm 7.49$ & $319 \pm 42.97$ & $42.45 \pm 6.77$ & $233.61 \pm 9.56$ & $17.8 \pm 3.33$ & $2.84 \pm 0.43$ & $34.41 \pm 5.25$ \\
\hline CV (\%) & 187.74 & 269.75 & 17.33 & 23.01 & 6.14 & 60.55 & 45.57 & 193.13 & 82.04 & 15.73 \\
\hline RDI & $500-1200$ & $100-500$ & 2000 & $320-420$ & $2400-5175$ & 2 & $0.4-1.2$ & $2-5$ & & $2-5$ \\
\hline
\end{tabular}

$* \overline{\text { Value bolded and asterisked refers to the highest concentration for a particular element; } \pm=\text { standard error of the }}$ mean of mineral element concentration in the accession. $\mathrm{CV}=$ Coefficient of Variation; $\mathrm{RDI}=$ recommended daily intake: (Source $=$ Dietary Reference, 1991); nd = not detected. 
Table 1 (Cont'd)*

\begin{tabular}{|c|c|c|c|c|c|c|c|c|c|c|}
\hline \multirow[b]{2}{*}{ Accession } & \multicolumn{4}{|c|}{ Macro elements } & \multicolumn{4}{|c|}{ Micro elements } & \multicolumn{2}{|c|}{ Trace elements } \\
\hline & $\mathrm{Ca}$ & $\mathrm{Cl}$ & $\mathrm{K}$ & $\mathrm{Mg}$ & $\mathrm{Na}$ & $\mathrm{Al}$ & $\mathrm{Cu}$ & $\mathrm{Mn}$ & As & $\mathrm{Br}$ \\
\hline Indiana & $68.39 \pm 10.26$ & $46.27 \pm 6.94$ & $13.42 \pm 2.01$ & $44.57 \pm 6.69$ & $521.32 \pm 78.20$ & $31.16 \pm 4.67$ & $\mathrm{Nd}$ & $36.35 \pm 5.45^{*}$ & $\mathrm{Nd}$ & $18.45 \pm 2.77$ \\
\hline Juaboso & $11.69 \pm 1.75$ & $83.44 \pm 12.52$ & $19.62 \pm 2.94$ & $59.59 \pm 8.94$ & $218.3 \pm 32.75$ & $35.26 \pm 5.64$ & $263.4 \pm 39.51$ & $24.01 \pm 4.29$ & $1.91 \pm 0.29$ & $31.42 \pm 4.72$ \\
\hline Kortebortor-ASR & $94.23 \pm 14.13$ & $43.01 \pm 6.45$ & $21.14 \pm 3.17$ & $46.86 \pm 7.03$ & $170.0 \pm 25.50$ & $36.53 \pm 5.88$ & $85.26 \pm 12.79$ & $11.00 \pm 2.49$ & $2.27 \pm 0.34$ & $36.10 \pm 5.42$ \\
\hline Kortebortor-BAR & $89.49 \pm 13.42$ & $58.06 \pm 8.71$ & $20.09 \pm 3.01$ & $51.47 \pm 7.72$ & $171.1 \pm 25.67$ & $37.89 \pm 6.06$ & $\mathrm{Nd}$ & $13.88 \pm 2.58$ & $1.38 \pm 0.20$ & $22.67 \pm 3.40$ \\
\hline Labadi & $10.63 \pm 1.59$ & $85.52 \pm 12.83$ & $23.14 \pm 3.47$ & $55.76 \pm 8.36$ & $316.78 \pm 47.52$ & $41.39 \pm 6.62$ & $276.4 \pm 41.46$ & $20.48 \pm 3.63$ & $\mathrm{Nd}$ & $27.43 \pm 4.11$ \\
\hline Legon Fingers & $90.61 \pm 13.59$ & $65.08 \pm 9.76$ & $15.32 \pm 2.30$ & $48.95 \pm 7.34$ & $570.7 \pm 85.61$ & $43.57 \pm 6.93$ & $\mathrm{Nd}$ & $15.50 \pm 2.88$ & $2.07 \pm 0.31$ & $34.67 \pm 5.20$ \\
\hline Mamolega & $90.9 \pm 13.63$ & $95.48 \pm 14.32^{*}$ & $40.79 \pm 6.12$ & $50.91 \pm 7.64$ & $778.5 \pm 11.60^{*}$ & $77.41 \pm 12.3^{*}$ & $\mathrm{Nd}$ & $18.03 \pm 3.55$ & $6.47 \pm 0.97$ & $104.6 \pm 15.69^{*}$ \\
\hline Nkran Nkuruma & $84.79 \pm 12.71$ & $52.89 \pm 7.93$ & $97.43 \pm 14.61^{\circ}$ & $51.27 \pm 7.69$ & $336.42 \pm 50.46$ & $34.69 \pm 5.59$ & $\mathrm{Nd}$ & $15.89 \pm 2.86$ & $\mathrm{Nd}$ & $53.18 \pm 7.98$ \\
\hline Volta & $68.63 \pm 10.29$ & $61.10 \pm 9.17$ & $18.45 \pm 2.77$ & $45.94 \pm 6.89$ & $415.26 \pm 62.29$ & $38.11 \pm 6.10$ & $\mathrm{Nd}$ & $11.63 \pm 2.61$ & $\mathrm{Nd}$ & $28.65 \pm 4.30$ \\
\hline Wune mana & $88.37 \pm 13.26$ & $72.54 \pm 10.88$ & $23.33 \pm 3.49$ & $50.96 \pm 7.64$ & $223.4 \pm 33.51$ & $70.11 \pm 11.15$ & $\mathrm{Nd}$ & $17.27 \pm 3.51$ & $2.18 \pm 0.33$ & $34.75 \pm 5.21$ \\
\hline Yeji-Local & $10.12 \pm 1.52$ & $78.85 \pm 11.83$ & $65.47 \pm 9.82$ & $55.71 \pm 8.36$ & $387.82 \pm 58.17$ & $50.21 \pm 7.98$ & $\mathrm{Nd}$ & $22.77 \pm 4.08$ & $\mathrm{Nd}$ & $46.78 \pm 7.02$ \\
\hline Mean & $64.31 \pm 9.64$ & $64.73 \pm 9.71$ & $32.06 \pm 4.81$ & $49.99 \pm 7.49$ & $319 \pm 42.97$ & $42.45 \pm 6.77$ & $233.61 \pm 9.56$ & $17.8 \pm 3.33$ & $2.84 \pm 0.43$ & $34.41 \pm 5.25$ \\
\hline CV (\%) & 187.74 & 269.75 & 17.33 & 23.01 & 6.14 & 60.55 & 45.57 & 193.13 & 82.04 & 15.73 \\
\hline RDI & $500-1200$ & $100-500$ & 2000 & $320-420$ & $2400-5175$ & 2 & $0.4-1.2$ & $2-5$ & & $2-5$ \\
\hline
\end{tabular}

*Value bolded and asterisked refers to the highest concentration for a particular element; $\pm=$ standard error of the mean mineral element concentration in the accession. $\mathrm{CV}=$ Coefficient of Variation; RDI $=$ recommended daily intake: $($ Source $=$ Dietary Reference, 1991); nd = not detected.

With respect to the micro elements, Indiana recorded the minimum Al concentration $(31.16 \pm 4.67 \mathrm{mg} / \mathrm{kg})$ while Mamolega recorded the maximum $(77.41 \pm 12.31 \mathrm{mg} / \mathrm{kg})$. Concentration of Arsenic (As) ranged from $1.24 \pm 0.34 \mathrm{mg} / \mathrm{kg}$ in Cape to $10.30 \pm 2.45 \mathrm{mg} / \mathrm{kg}$ in Asontem-ASR; Br concentration ranged from $15.54 \pm 2.33$ $\mathrm{mg} / \mathrm{kg}$ (Asontem-ASR) to $104.6 \pm 15.69 \mathrm{mg} / \mathrm{kg}$ (Mamolega). Similarly, Kortebortor-ASR recorded the minimum $\mathrm{Cu}$ concentration $(85.26 \pm 12.79 \mathrm{mg} / \mathrm{kg})$ while Cape again had the maximum $(424.5 \pm 63.67 \mathrm{mg} / \mathrm{kg})$. On the other hand, Indiana registered the maximum Mn concentration $(36.35 \pm 5.45 \mathrm{mg} / \mathrm{kg}$ ) with the minimum registered by Kortebortor-ASR $(11.00 \pm 2.49 \mathrm{mg} / \mathrm{kg})$. No single accession recorded the maximum concentration for all the elements analysed though the accession Asontem-BAR which recorded maximum concentrations of $\mathrm{Mg}$ and $\mathrm{Cl}$, also recorded significantly high concentrations of other elements analysed.

On the whole, there were high variabilities among the okra accessions for concentrations of all five essential macro elements in the edible fruits as detected using INAA. Variabilities among accessions for concentration of the three micro elements and two trace elements in the fresh fruits were also high. The concentrations of $\mathrm{Cu}$ and $\mathrm{As}$ in some accessions were below levels detectable using INAA.

Calcium is one of the predominant essential elements in foods. All the accessions recorded very low amounts of calcium compared to the recommended daily allowance of $500-1200 \mathrm{mg} / \mathrm{kg}$ (Oduro et al., 2008; $\mathrm{http} / / /$ nutritiondata.self.com/facts/cereal-grains-and-pasta/5707/2). In a similar study, Ismail et al. (2011) using Atomic Absorption Spectrometry (AAS) reported higher concentrations of Ca in okra (210 mg/kg), tomato (335 $\mathrm{mg} / \mathrm{kg}$ ), chilli pepper $(305 \mathrm{mg} / \mathrm{kg})$, onion $(265 \mathrm{mg} / \mathrm{kg})$, cucumber $(180 \mathrm{mg} / \mathrm{kg})$ and carrot $(220 \mathrm{mg} / \mathrm{kg})$. Howe et al. (2005) working in Ethiopia and using Neutron Activation Analysis (NAA) as well as Flame and Graphite Furnace Atomic Absorption Spectrophotometry (FGFAAS) in a study of elemental composition of five categories of Jamaican foods reported $360 \mathrm{mg} / \mathrm{kg} \mathrm{Ca}$ as against $139 \mathrm{mg} / \mathrm{kg} ; 133 \mathrm{mg} / \mathrm{kg} ; 135 \mathrm{mg} / \mathrm{kg}$ and $7.65 \mathrm{mg} / \mathrm{kg}$ Ca recorded for same foods in Denmark, UK, USA and Nigeria, respectively. Accessions with significant concentration of this element could be developed for use in supplementation of other sources of $\mathrm{Ca}$ to meet the recommended dietary intake.

Chorine is an essential nutrient in human nutrition required for healthy functions of nervous and digestive systems. It is present in crustal rock at a concentration of about $170 \mathrm{mg} / \mathrm{kg}$ and preferentially adheres to soil particles. The concentrations of $\mathrm{Cl}$ recorded elsewhere for fresh broccoli, cucumber, melon, green onion, chilli pepper, tomato and apples ranged from $100-150 \mathrm{mg} / \mathrm{kg} ; 100-150 \mathrm{mg} / \mathrm{kg} ; 100-150 \mathrm{mg} / \mathrm{kg} ; 100-150 \mathrm{mg} / \mathrm{kg} ; 250-400 \mathrm{mg} / \mathrm{kg}$; $200-350 \mathrm{mg} / \mathrm{kg}$ and 100-1500 mg/kg, respectively (Suslow, 2006). These values are higher than those recorded in this study. Concentration of chlorine in the accessions studied was highly variable. This could be attributed to 
influence of soil geochemical processes, anthropogenic influences and previous agronomic practices on experimental site (Suslow, 2006).

Variability in concentration of $\mathrm{K}$ among the accessions was low and the individual values were also below the RDI. However, these values were above those reported by Benchasri (2012) for okra and Adotey et al. (2009) for tomato. Similarly, variability in concentration of $\mathrm{Mg}$ among accessions recorded in this study was also low. Values recorded were below those reported for okra (323 mg/kg); mango (326 mg/kg); carrot (2970 mg/kg); onion (1705 $\mathrm{mg} / \mathrm{kg}$ ); cucumber (392 mg/kg); tomato (418 mg/kg) and chilli pepper (236 mg/kg) (Ismail et al., 2011) but higher than those reported by Adotey et al. (2009) and Zaichick (2002) for tomato.

Results of this study indicate that okra pods contain high levels of Na compared to other elements. This is consistent with the report by Kumar et al. (2010). Ismail et al. (2011) reported varying Na concentrations in okra $(1240 \mathrm{mg} / \mathrm{kg})$; guava $(580 \mathrm{mg} / \mathrm{kg})$; mango $(4000 \mathrm{mg} / \mathrm{kg})$; cucumber $(5250 \mathrm{mg} / \mathrm{kg}) ;$ tomato $(7350 \mathrm{mg} / \mathrm{kg})$; chilli pepper $(4050 \mathrm{mg} / \mathrm{kg})$; onion $(4600 \mathrm{mg} / \mathrm{kg})$ and carrot $(4900 \mathrm{mg} / \mathrm{kg})$ which compare well with Na concentrations in the current study. Variability among accessions for the concentration of $\mathrm{Na}$ was very low.

Concentrations of all three micro elements $(\mathrm{Al}, \mathrm{Cu}$ and $\mathrm{Mn}$ ) detected were variable among the accessions. Quartey et al. (2012) and Adotey et al. (2009) also reported high variabilities in concentrations of these elements in tomato. The concentrations of $\mathrm{Al}$ recorded for all accessions were comparatively higher than values recorded for clover $(23.6 \mathrm{mg} / \mathrm{kg})$, oats $(7.3 \mathrm{mg} / \mathrm{kg})$, bean $(5.1 \mathrm{mg} / \mathrm{kg})$, green lentil $(6.6 \mathrm{mg} / \mathrm{kg})$, spinach $(12.6 \mathrm{mg} / \mathrm{kg})$, corn $(11.90$ $\mathrm{mg} / \mathrm{kg}$ ), red lentil (3.7 mg/kg) and rice (8.4 mg/kg) as reported by Hicsonmez et al. (2012). On the other hand, $\mathrm{Mn}$ levels reported in okra $(323 \mathrm{mg} / \mathrm{kg})$; mango $(326 \mathrm{mg} / \mathrm{kg})$; carrot $(2970 \mathrm{mg} / \mathrm{kg})$; onion $(1705 \mathrm{mg} / \mathrm{kg})$; cucumber $(392 \mathrm{mg} / \mathrm{kg})$; tomato $(418 \mathrm{mg} / \mathrm{kg})$ and chilli pepper $(236 \mathrm{mg} / \mathrm{kg})$ by Ismail et al. (2011) are higher than those reported in this study.

Content of $\mathrm{Cu}$ in the fresh fruits of okra was detectable in only six out of the 22 accessions with a mean of $233.6 \mathrm{mg}$ which far exceed the RDI. Differential abilities of some accessions to uptake and accumulate $\mathrm{Cu}$ in the fruits may account for the results obtained. Ismail et al. (2011) recorded $\mathrm{Cu}$ concentrations of $100 \mathrm{mg} / \mathrm{kg} ; 100 \mathrm{mg} / \mathrm{kg} ; 130$ $\mathrm{mg} / \mathrm{kg} ; 170 \mathrm{mg} / \mathrm{kg} ; 500 \mathrm{mg} / \mathrm{kg} ; 900 \mathrm{mg} / \mathrm{kg} ; 1400 \mathrm{mg} / \mathrm{kg}$ and $1400 \mathrm{mg} / \mathrm{kg}$ in okra, cucumber, tomato, chilli pepper, guava, mango, onion and carrot respectively in Pakistan. Copper is one of the essential micronutrients, hence its adequate supply in vegetables must be supplemented by application of synthetic or organic fertilisers (Itanna, 2002). There was high variability in the concentration of Mn among the accessions. Values obtained far exceed the RDI.

Concentration of As in the fresh fruits of the accessions exceed the range $(0.005-0.54 \mathrm{mg} / \mathrm{kg})$ reported by Al Rmalli et al. (2005) for vegetables imported from Bangladesh comparable to values for freshwater fish $(0.097-1.318 \mathrm{mg} / \mathrm{kg})$. The As content of the vegetables from UK was approximately 0.002 to $0.003 \mathrm{mg} / \mathrm{kg}$ lower than those observed for the vegetables imported from Bangladesh (Al Rmalli et al., 2005) comparing very well with results of this study. The high As content in accessions of Abelmoschus spp (L.) could have originated from the seeds or the water used in the germination process. The accessions of okra appear to contain relatively high levels of As, although uptake in general is contingent on both plant species and elemental availability (She \& Kheng, 1992). As is a highly toxic element and its presence in food composites is a matter of concern to the well-being of both humans and animals. Source of water, industrial effluents and contaminated water for irrigating farmland have become notorious sources of heavy metal pollution of agricultural lands. As could have been added to the soil water system from effluents emanating from the ceramic and glass industries of Aburi and the Akuapim ridge of the city of Accra. Bioaccumulation of As would be hazardous to humans and animals because of its perceived relationship to cancer, arteriosclerosis and chronic liver disease.

Variability in the concentrations of $\mathrm{Br}$ among the 22 okra accessions was low. This contrasts with results reported by Howe et al. (2005) for fruits and leafy vegetables $(0.07-5.5 \mathrm{mg} / \mathrm{kg})$ in Jamaica and UK, and also by far exceeds the RDI for Br (Dietary Reference, 1991). This is crucial as a result of the emerging status of okra (Abelmoschus spp (L.) as a non-traditional export crop in meeting acceptable international export standards. In general, variability in concentrations of the various elements among the accessions may be attributable to genotypic differences with respect to mineral uptake and accumulation and also influence of geochemical reactions within the soil at site such as speciation, soil-to-plant interactions as well as anthropogenic activities in and around the experimental site.

\subsection{Association Between Mineral Elements}

Table 2 shows the association between pairs of elements in the accessions analysed. Ca showed strong and positive association with three other elements $\mathrm{Cl}, \mathrm{Mg}$ and $\mathrm{Cu}$ but was negatively correlated with $\mathrm{Na}, \mathrm{Al}, \mathrm{As}, \mathrm{Br}$ and $\mathrm{Mn}$. Its association with $\mathrm{K}$ was very weak though positive. $\mathrm{Cl}$ was moderately correlated with four elements, $\mathrm{K}, \mathrm{Mg}, \mathrm{Na}$ 
and $\mathrm{Cu}$ but negatively associated with $\mathrm{Al}$, $\mathrm{As}$ and $\mathrm{Mn}$. Its association with $\mathrm{Br}$ was very weak though positive. $\mathrm{K}$ exhibited positive association with the other four macro elements $\mathrm{Ca}, \mathrm{Cl}, \mathrm{Mg}$ and $\mathrm{Na}$ all of which were not significant. Similarly, it exhibited positive association with $\mathrm{Br}$ and $\mathrm{Cu}$ but was weakly and negatively associated with $\mathrm{Al}$, As and $\mathrm{Mn}$. Mg was significantly and positively associated with $\mathrm{Ca}$ but was negatively correlated with $\mathrm{Na}$, $\mathrm{Al}$, As and Mn but positively correlated with $\mathrm{Br}$. Na was moderately and strongly associated with $\mathrm{K}$ and $\mathrm{Br}$ respectively. It was however, weakly associated with the rest of the elements. There was no positive significant association between $\mathrm{Al}$ and the rest of the elements. Similarly, association between As and the rest of the elements was mostly negative and weak. There was a strong association between $\mathrm{Br}$ and $\mathrm{K}$ as well as $\mathrm{Na}$. Other associations were moderate or weak and negative. Relationships between $\mathrm{Cu}$ and $\mathrm{Na}$ as well as $\mathrm{Al}$ were weak though positive. The same element was weakly and negatively correlated with the rest of the elements except $\mathrm{Ca}$ which showed negative but moderate association.

Table 2. Correlations among ten mineral elements in 22 accessions of Abelmoschus spp (L)*

\begin{tabular}{cllllllllll}
\hline Mineral element & $\mathrm{Ca}$ & $\mathrm{Cl}$ & $\mathrm{K}$ & $\mathrm{Mg}$ & $\mathrm{Na}$ & $\mathrm{Al}$ & $\mathrm{Cu}$ & $\mathrm{Mn}$ & $\mathrm{As}$ & $\mathrm{Br}$ \\
\hline $\mathrm{Ca}$ & & & & & & & & & \\
$\mathrm{Cl}$ & 0.732 & & & & & & & & \\
$\mathrm{~K}$ & 0.101 & 0.330 & & & & & & & \\
$\mathrm{Mg}$ & 0.687 & 0.464 & 0.017 & & & & & & \\
$\mathrm{Na}$ & -0.137 & 0.290 & 0.411 & -0.105 & & & & & & \\
$\mathrm{Al}$ & -0.367 & -0.219 & -0.032 & -0.237 & 0.333 & & & & \\
$\mathrm{Cu}$ & 0.636 & 0.444 & 0.175 & 0.565 & -0.064 & -0.164 & & & \\
$\mathrm{Mn}$ & -0.442 & -0.165 & -0.010 & -0.221 & 0.200 & 0.225 & -0.141 & & & \\
$\mathrm{As}$ & -0.015 & -0.089 & -0.102 & -0.416 & -0.238 & 0.014 & -0.200 & -0.170 & & \\
$\mathrm{Br}$ & -0.034 & 0.192 & 0.516 & 0.033 & 0.606 & -0.063 & -0.001 & -0.125 & -0.191 & \\
\hline
\end{tabular}

$\mathrm{P}(\leq 0.05)$ is considered significant.

The strong associations between $\mathrm{Ca}$ and $\mathrm{Cl}$ as well as $\mathrm{Mg}$ are desirable as these elements are required in relatively large amount in the diets of humans (Hicsonmez et al., 2012). This suggests that it may be possible for the breeder to simultaneously select for higher concentrations of these pairs of elements in a breeding programme involving biofortification. Similarly, strong correlations between $\mathrm{Cu}$ and $\mathrm{Ca}$ as well as $\mathrm{Mg}$ suggest that positive gains may be made by the breeder in selecting for either pair of elements.

Historically, international breeding efforts in okra have been oriented towards intensive cultivation with high production in a short period (early maturity) and wide adaptation (photoperiod insensitivity, resistance to insects and diseases) (Benchasri, 2012). However, the importance of the quality of food source for reducing micro nutrient deficiencies has assumed prominence of late. There is now greater recognition of the global prevalence of many forms of micro nutrient malnutrition (National Academies Press, 2006). Hence, enhancing nutritional quality through diet selection holds great prospects of success in the near future.

Okra has no intraspecific barrier to crossability (Ahiakpa et al., 2013; Anonymous, 2010). It is a good candidate for inclusion in many diets by virtue of the significant concentration of several mineral elements in its edible fruits. Superior lines such as Mamolega, Yeji-Local, Asontem-BAR, Clemson spineless, Cape, Atomic, Asontem-GAR, Indiana and Legon fingers may be selected for future hybridisation work aimed at further improvement in mineral element contents alongside fresh fruit yield and other desirable traits.

\section{Conclusions}

Ten essential mineral elements were detected among the accessions with varying prevalence levels indicating high level of genetic variability among the accessions with respect to concentrations of these elements in their edible fruits. Concentrations of micro and trace elements ( $\mathrm{Al}, \mathrm{As}, \mathrm{Br}, \mathrm{Cu}$ and $\mathrm{Mn}$ ), in all accessions were above their recommended daily dietary intake (RDI); therefore, excess intake of these varieties could pose health risk to consumers. However, concentrations of the macro elements $(\mathrm{Ca}, \mathrm{Cl}, \mathrm{K}, \mathrm{Mg}$ and $\mathrm{Na}$ ) were below their RDI (s). Hence, consumption of okra ought to be supplemented by other food sources of these elements in order to meet 
their RDIs. Three local (Mamolega, Nkran Nkuruma, Asontem-BAR) and one exotic (Indiana) accessions may be selected as parents for future breeding work aimed at concentrating optimum levels of several essential elements in a single variety together with high yield and adaptation to local environmental conditions. Strong positive associations existing between most pairs of elements contained in the accessions may be key in future breeding work involving biofortification, as selecting for one element may imply simultaneous selection of another.

\section{References}

Adotey, D. K., Serfor-Armah, Y., Fianko, J. R., \& Yeboah, P. O. (2009). Essential elements content in core vegetables grown and consumed in Ghana by instrumental neutron activation analysis. African Journal of Food Science, 3(9), 243-244.

Ahiakpa, J. K., Kaledzi, P. D., Adi, E. B., Peprah, S., \& Dapaah, H. K. (2013). Genetic Diversity, Correlation and Path Analyses of Okra (Abelmoschus spp L.) Germplasm collected in Ghana. International Journal of Development and Sustainability, 2(2), 1396-1415.

Al Rmalli, S. W., Haris, P. I., Harrington, C. F., \& Ayub, M. (2005). A survey of arsenic in foodstuffs on sale in the United Kingdom and imported from Bangladesh, Science of the Total Environment, 33(1-3), 23-30. http://dx.doi.org/10.1016/j.scitotenv.2004.06.008

Anonymous. (2010). The Biology of Okra (pp. 6-29). Department of Biotechnology, Ministry of Science and Technology and Ministry of Environment and Forest, Government of India.

Benchasri, S. (2012). Okra (Abelmoschus esculentus (L.) Moench) as a Valuable Vegetable of the World. A review paper. Ratarstvo i Povrtarstvo, 49, 105-112. http://dx.doi.org/10.5937/ratpov49-1172

Dietary Reference. (1991). Dietary Reference Values for Food Energy and Nutrients for the United Kingdom Report on Health and Social Subjects 41. Department of Health, HMSO, London.

FAOSTAT. (2012). Food and Agriculture Organisation Statistical Database. Retrieved from http://faostat.fao.org/site/567/default.aspx

Gulsen, O., Karagul, S., \& Abak, K. (2007). Diversity and relationships among Turkish okra germplasm by SRAP and phenotypic marker polymorphism. Biologia Bratislava, 62, 41-45. http://dx.doi.org/10.2478/s11756-007-0010-y

Hicsonmez, U., Ozdemir, C., Cam, S., Ozdemir, A., \& Erees, F. S. (2012). Major-minor element analysis in some plant seeds consumed as feed in Turkey. Natural Science, 4(5), 298-303. http://dx.doi.org/10.4236/ns.2012.45042

Howe, A., Fung, H. L., Lalor, G., Rattray, R., \& Vutchkov, M. (2005). Elemental composition of Jamaican foods 1: A survey of five food crop categories. Environmental Geochemistry and Health, 27, 19-30, http://dx.doi.org/10.1007/s10653-004-5671-7

Ismail, F., Anjum, M. R., Mamon, A. N., \& Kazi, T. G. (2011). Trace Metal Contents of Vegetables and Fruits of Hyderabad Retail Market. Pakistan Journal of Nutrition, 10(4), 365-372, http://dx.doi.org/10.3923/pjn.2011.365.372

Itanna, F. (2002). Metals in leafy vegetables grown in Addis Ababa and toxicological implications. Ethiopian Journal of Health Development, 16(3), 295-302. http://dx.doi.org/10.4314/ejhd.v16i3.9797

Kolawole, O. M., Ajiboye, A. E., Aturu, E. E., \& Anibijuwon, I. I. J. (2011). Effect of Solar Drying on the Proximate and Microbial Composition of Abelmoschus esculentus (L.). Microbiology and Biotechnology Research, 1(1), 71-81.

Kumar, S., Dagnoko, S., Haougui, A., Ratnadass, A., Pasternak, D., \& Kouame, C. (2010). Okra (Abelmoschus spp.) in West and Central Africa: Potential and Progress on its Improvement. A special review. African Journal of Agricultural Research, 5(25), 3590-3598.

Lamont, Jr., W. (1999). Okra a versatile vegetable crop. Horticultural Technology, 9, 179-184.

National Academies Press. (2006). Lost Crops of Africa Volume II: Vegetables (pp. 287-301). Formerly National Academy Press. Retrieved 10th October, 2011, from www.nap.edu/catalog/11763.html

Oduro, I., Ellis, W. O., \& Owusu, D. (2008). Nutritional potential of two leafy vegetables: Moringa oleifera and Ipomoea batatas leaves. Scientific Research and Essay, 3(2), 057-060. 
Oppong-Sekyere, D., Akromah, R., Nyamah, E. Y., Brenya, E., \& Yeboah, S. (2012). Evaluation of some okra (Abelmoschus spp (L.)) germplasm in Ghana. African Journal of Plant Science, 6(5), 166-178. http://dx.doi.org/10.5897/AJPS11.248

Quartey, K. E., Opata, N. S., Amoatey, H. M., \& Klu, G. Y. P. (2012). Elemental Composition in Fruits of Gamma-Radiation Induced Variant Lines of Solanum pimpinellifolium (L.). Asian Journal of Agricultural Sciences, 4(3), 198-204.

Saifullah, M., \& Rabbani, M. G. (2009). Evaluation and characterisation of okra (Abelmoschus esculentus (L.) Moench.) genotypes. SAARC Journal of Agriculture, 7, 92-99.

She, L. K., \& Kheng, L. C. (1992). Arsenic Contents in Some Malaysian Vegetables. Pertanika, 15(2), $171-173$.

Sinnadurai, S. (1973). Vegetable Production in Ghana. Acta Horticulturae, 33, 25-28.

Statgraphics. (2010). Statgraphics Centurion XVI, version 16.1.11, Windows-based statistical software, (32-bit) C 2010 Statpoint Technologies, Inc. Multilingual, USA.

Suslow, T. (2006). Chlorination in the production and postharvest handling of fresh fruits and vegetables, postharvest pathology, transportation \& distribution. University of California - Davis.

Tyler, H. A., Buss, D. H., \& Knowles, M. E. (1989). The Nutritional Importance of Vegetables. Acta Horticulturae, 244, 201-208.

Zaichick, V. (2002). Instrumental Neutron Activation Analysis of minor and trace elements in food in the Russian region that suffered from the Chernobyl disaster. Food and Nutrition Bulletin, 23(3), 191-194.

\section{Copyrights}

Copyright for this article is retained by the author(s), with first publication rights granted to the journal.

This is an open-access article distributed under the terms and conditions of the Creative Commons Attribution license (http://creativecommons.org/licenses/by/3.0/). 